Florida International University FIU Digital Commons

Cuban Research Institute Events

Cuban Research Institute

$10-18-2011$

\title{
From Rainforest to Cane Field in Cuba: An Environmental History since 1492
}

Cuban Research Institute, Florida International University

Follow this and additional works at: https://digitalcommons.fiu.edu/cri_events

Part of the Latin American Studies Commons

\section{Recommended Citation}

Cuban Research Institute, Florida International University, "From Rainforest to Cane Field in Cuba: An Environmental History since 1492" (2011). Cuban Research Institute Events. 192.

https://digitalcommons.fiu.edu/cri_events/192

This work is brought to you for free and open access by the Cuban Research Institute at FIU Digital Commons. It has been accepted for inclusion in Cuban Research Institute Events by an authorized administrator of FIU Digital Commons. For more information, please contact dcc@fiu.edu. 


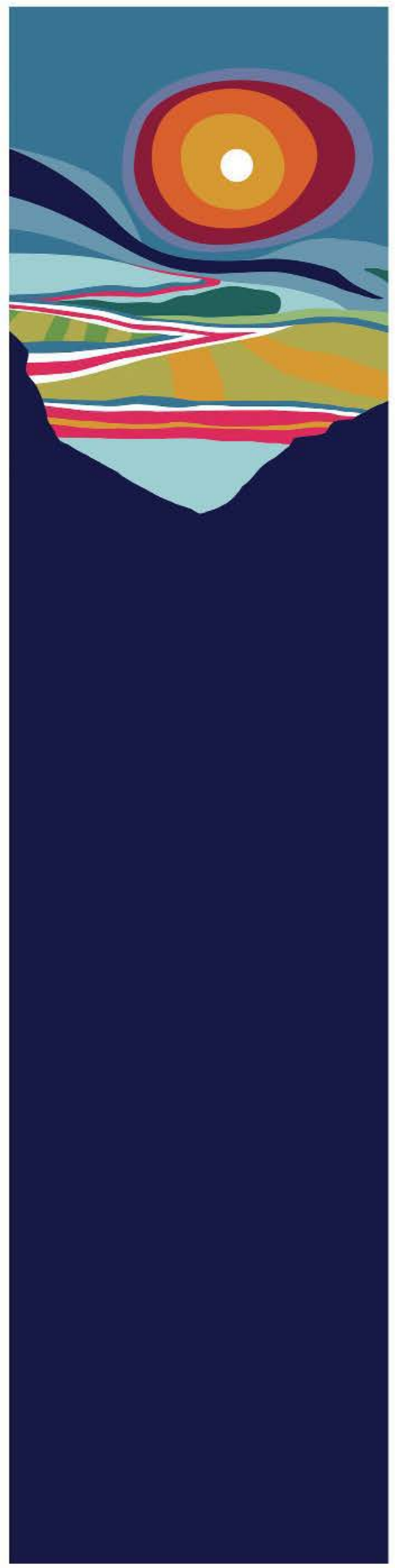

Cordially invites you to a book presentation and lecture

\section{"From Rainforest to Cane Field in Cuba: An Environmental History since 1492"}

with author

Reinaldo Funes Monzote, Ph.D.

\section{Tuesday, October 18, 2011 | 5:00p.m.}

FIU Modesto A. Maidique Campus

Graham Center, Room 150

In this book, the 2009 recipient of the Elinor Melville Prize for Latin American Environmental History from the Conference on Latin American History award, Reinaldo Funes Monzote provides a comprehensive environmental history of Cuba since 1492 and its transformation from a mostly forested island to one dominated by sugar cane. It examines the human induced evolution of the Cuban landscape since the arrival of Columbus.

Reinaldo Funes Monzote, is an associate professor of history at the University of Havana. He holds a Ph.D. from Universitat Jaume I, Spain. He has been a visiting instructor and research guest in universities from Spain and Brazil and has been a guest lecturer in numerous countries around the globe.

Event is free and open to the public. A reception sponsored by DOHGSA (the history department graduate student association) will be held following the event in the History department conference room, DM370. For additional information and to RSVP call LACC at (305)348-2894.

Co-sponsored by the Department of History, at FIU 